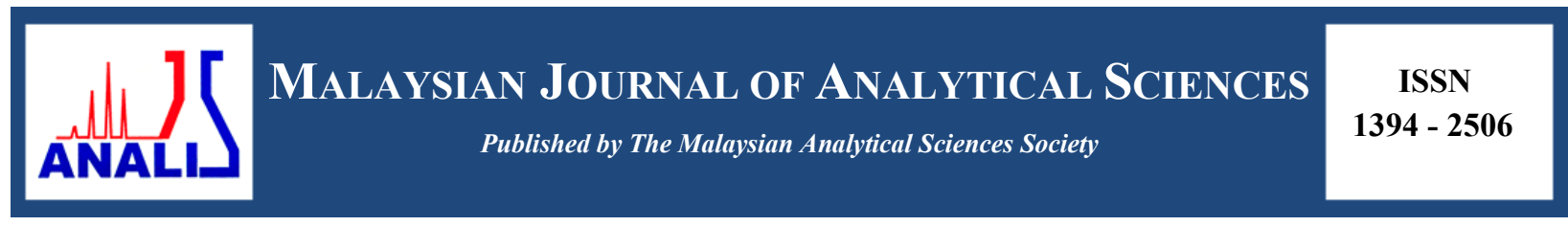

\title{
NEW DITERPENOIDS FROM THE ROOTS OF Croton hirtus (EUPHORBIACEAE)
}

\section{(Diterpenoid-Diterpenoid Terbaharu Daripada Akar Croton hirtus (Euphorbiaceae))}

\author{
Andi Rifki Rosandy ${ }^{1}$, Anis Asmi Azman ${ }^{1}$, Rozida Mohd Khalid ${ }^{1}$, Rizafizah Othaman ${ }^{1}$, Azwan Mat Lazim ${ }^{1}$, \\ Iqbal M. Choudary ${ }^{2}$, Yana Maulana Syah ${ }^{3}$, Jalifah Latip ${ }^{1}$, Ikram Md. Said ${ }^{1}$, Muntaz Abu Bakar ${ }^{1 *}$ \\ ${ }^{I}$ School of Chemical Sciences and Food Technology, Faculty of Science and Technology, \\ Universiti Kebangsaan Malaysia,43600 UKM Bangi, Selangor, Malaysia \\ ${ }^{2}$ Hussain Ebrahim Jamal Research Institute of Chemistry, \\ University of Karachi, Karachi, 75270, Pakistan \\ ${ }^{3}$ Organic Chemistry Division, Faculty of Mathematics and Natural Sciences, \\ Institut Teknologi Bandung, Jalan Ganesha 10, Bandung 40132, Indonesia \\ *Corresponding author: muntaz@ukm.edu.my
}

Received: 14 February 2017; Accepted: 28 December 2017

\begin{abstract}
The root of Croton hirtus was collected at Tanjung Sepat, Banting for study of its chemical compounds. This sample was dried before being ground and extracted using the methanol solvent at room temperature for three days yielding 18.25 gram of crude extract. The crude extracts obtained were analysed using thin layer chromatography (TLC) then fractionated via vacuum column chromatography (VLC) and proceed the isolation using radial chromatography (RC) to get the pure compounds. The pure compounds obtained were elucidated by nuclear magnetic resonance (NMR), Fourier Transform Infrared (FT-IR) and mass spectroscopy to confirm their structures and from that analysis, the compounds were identified as two new compounds naming (-)-5,8-dihydroxyjatrophan-3-one (1) and (+)-14,16,17-trihydroxykauran-1-on (2) with total weight $4.9 \mathrm{mg}$ and $4.5 \mathrm{mg}$ respectively. This two compound were reported for this time on this genus.
\end{abstract}

Keywords: Croton hirtus, diterpenoid, euphorbiaceae

\section{Abstrak}

Akar Croton hirtus dikumpulkan di Tanjung Sepat, Banting untuk mengkaji sebatian kimianya. Sampel ini dikeringkan sebelum dikisar dan diekstrak dengan menggunakan pelarut metanol pada suhu bilik selama tiga hari dan ia menghasilkan $18.25 \mathrm{~g}$ ekstrak mentah. Ekstrak mentah yang diperoleh dianalisis dengan menggunakan kromatografi lapisan nipis (TLC) kemudian difraksikan melalui kromatografi cecair vakum (VLC) dan pengasingan diteruskan dengan menggunakan kromatografi radial (RC) untuk mendapatkan sebatian tulen. Sebatian tulen yang diperoleh ditentukan oleh resonan magnetik nuklear (RMN), inframerah transformasi Fourier (FTIR) dan spektroskopi jisim untuk mengesahkan struktur mereka dan dari analisis itu, sebatian telah dikenal pasti sebagai dua sebatian baru yang diberi nama (-)-5,8- dihidroksijatrophan-3-one (1) dan (+)-14,16,17trihidroksikauran-1-on (2) dengan jumlah berat masing-masing sebanyak $4.9 \mathrm{mg}$ dan $4.5 \mathrm{mg}$. Kedua-dua sebatian ini dilaporkan buat kali pertama bagi genus ini.

Kata kunci: Croton hirtus, diterpenoid, euphorbiaceae 


\section{Introduction}

Croton hirtus, also known as Croton glandulosus, is a shrub belonging to genus Croton and family Euphorbiaceae. They were distributed widespread around the world as trees, shrubs and herbs with about 1300 species. Croton is widely found in Malaysia and in several areas of Indonesia except Kalimantan, Sulawesi and the Sunda Islands [1]. Extensive work has been carried out on various species of Croton, resulting in the isolation of mainly terpenoid class of compounds, namely sesquiterpenoids [2 - 5], diterpenoids [6 - 13], and triterpenoids [14 - 17]. Nonterpenoid was isolated such as alkaloids, flavonoids, lignans and megastigmane glycosides [18]. Work on Brazilian C. hirtus has mainly concentrated on diterpenes [19] and essential oils [20]. So, with this background information, the aim of this present study are to analyse and characterize two new diterpenoid that have been isolated from root of genus using the spectroscopy NMR (1D and 2D), FT-IR and mass spectroscopy.

\section{Materials and Methods}

\section{Raw materials}

The roots of $C$. hirtus were collected in Tanjung Sepat, Banting, Selangor, Malaysia and herbarium specimen (SM461) was deposited in the Herbarium of Universiti Kebangsaan Malaysia.

\section{Extraction and isolation}

Dried and ground roots of $C$. hirtus $(415 \mathrm{~g})$ were extracted with methanol to give a dark green extract $(18.25 \mathrm{~g})$. The crude extract $(18.25 \mathrm{~g})$ was partitioned between chloroform and water (1:1) after which the chloroform extract was further extracted with $10 \% n$-hexane and 90\% methanol to give methanol sub-extract. The sub-extract (3.52 g) was fractionated by using silica gel vacuum liquid chromatography eluted with increasing polarity of $n$-hexane- ethyl acetate to give ten fractions. The eluents that showed the same profile on thin layer chromatography (TLC) were combined to give four fractions (I-IV). Purification of fraction II $(0.2027 \mathrm{~g})$ was carried out using radial chromatography (RC) with silica gel plate of $1 \mathrm{~mm}$ thickness eluted with 60:40 $n$-hexane-ethyl acetate in 5\% polarity increment to yield compound $1(4.9 \mathrm{mg})$. Purification of fraction III $(0.3163 \mathrm{~g})$ was also carried out in a similar manner eluting with $1: 1 n$-hexane-ethyl acetate producing sub-fractions III $^{\mathrm{a}}-$ III $^{\mathrm{f}}$. Sub-fraction $\left(\right.$ III ${ }^{\mathrm{c}}=0.0221$ g) was further purified using RC with silica gel plate of $1 \mathrm{~mm}$, eluting with 30:70 $n$-hexane-ethyl acetate, which resulted in the isolation of compound $2(4.5 \mathrm{mg})$.

\section{Results and Discussion \\ (-)-5,8-dihydroxyjatrophan-3-one (1), $[\alpha]_{\mathrm{D}}{ }^{25}-102.50\left(c 0.40, \mathrm{CHCl}_{3}\right)$, was isolated as a pinkish oily material with molecular formula $\mathrm{C}_{20} \mathrm{H}_{30} \mathrm{O}_{3}$, obtained by HR-CI-MS [M+1] $319.2276 \mathrm{~m} / \mathrm{z}$. The IR spectra exhibited absorptions for hydroxyl groups $\left(3402 \mathrm{~cm}^{-1}\right)$, cyclic aliphatic group $\left(2922 \mathrm{~cm}^{-1}\right)$, and $\alpha, \beta$-unsaturated carbonyl group (1709 and $1647 \mathrm{~cm}^{-1}$ ) (Figure 1).}

The ${ }^{13} \mathrm{C}$ spectrum indicated the presence of 20 carbons consisting of five methyls, three methylenes, seven methines and five quaternary carbons. The most highly deshielded signal at $\delta_{\mathrm{C}} 199.7$ (C-3) integrated for carbon attributed to a carbonyl group, three signals for methane carbon at $\delta_{\mathrm{C}} 145.3(\mathrm{C}-1), 125.7(\mathrm{C}-7)$ and $119.4(\mathrm{C}-12)$ indicating the presence of olefinic carbons that are linked with olefinic-quaternary carbons at $\delta_{c} 134.6(\mathrm{C}-2), 143.7$ (C-6) and 137.7 (C-13), while the other two shielded methine carbons at $\delta_{c} 77.4(\mathrm{C}-5)$ and 67.7 (C-8) belongs to two carbinol groups in the molecule, while the other three carbons at $\delta_{c} 25.5(\mathrm{C}-9), 31.6(\mathrm{C}-11)$ and $39.9(\mathrm{C}-14)$ is indicative of the aliphatic component of the cyclic system, which also contains five methyl carbons from $\mathrm{C}-16$ to $\mathrm{C}-20$. The $\mathrm{DBE}$ value of $\mathrm{C}_{20} \mathrm{H}_{30} \mathrm{O}_{3}$ is 6 , indicating that the compound consists of four double bonds (three olefinics and one carbonyl) and two rings of aliphatic group. The ${ }^{1} \mathrm{H}-\mathrm{NMR}$ spectrum showed 18 proton resonance signals representing 30 protons. Eighteen of the signals came from the three signals, three each from methyl group at $\mathrm{H}-16\left(\delta_{\mathrm{H}} 1.95, \mathrm{~s}\right)$, $\mathrm{H}-17\left(\delta_{\mathrm{H}} 1.72, \mathrm{~s}\right)$, and H-20 $\left(\delta_{\mathrm{H}} 1.61, \mathrm{~s}\right)$ bonded to an olefinic carbon while the other two protons at $\mathrm{H}-18\left(\delta_{\mathrm{H}} 1.03\right.$, s) and H-19 $\left(\delta_{\mathrm{H}} 1.17, \mathrm{~s}\right)$ represent the two non- equivalent methyl protons. Furthermore, six signals of methylene protons and seven signals of methine protons are from a cyclic aliphatic or jatrophane skeleton as the main structure in the molecule (Figure 2). 


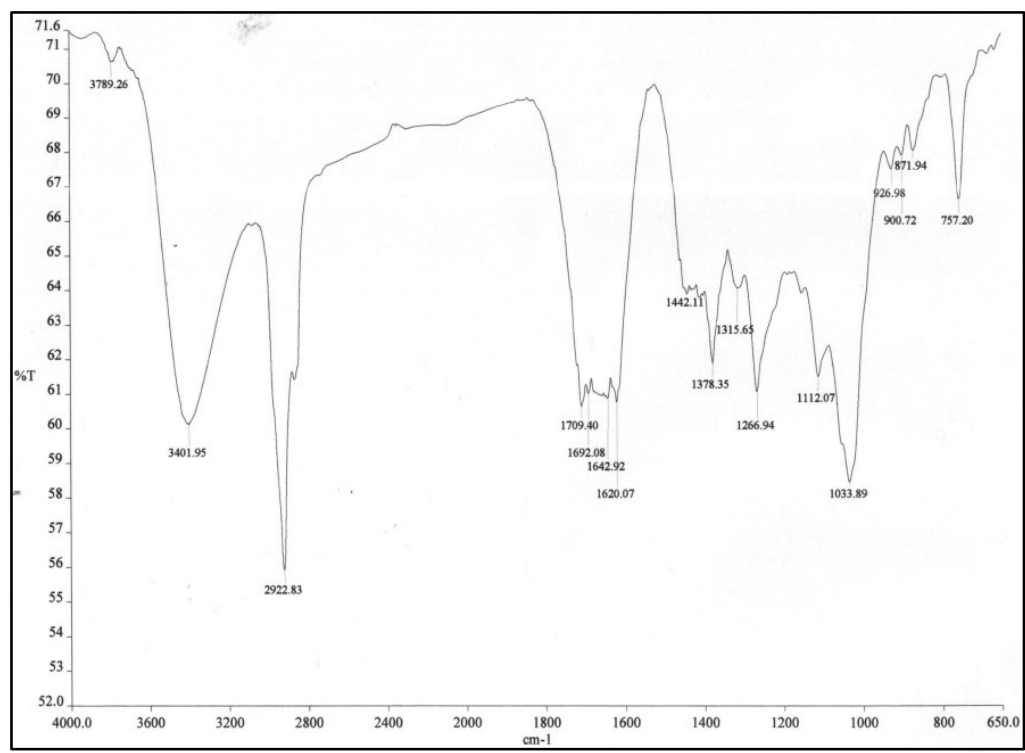

Figure 1. FTIR spectrum of (-)-5,8-dihydroxyjatrophan-3-one

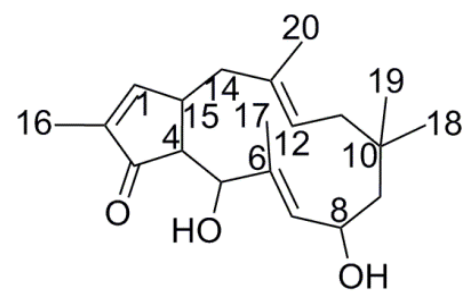

Figure 2. Chemical structure of (-)-5,8-dihydroxyjatrophan-3-one

The structure was confirmed by using 2D NMR. The HMBC experiment showed H-16 in correlation with C-1 and $\mathrm{C}-3$, confirming the position of this methyl group bonded to $\mathrm{C}-2$ at the cyclopentane ring and also $\mathrm{C}-20$ with methylene (C-14) and olefinic-methine (C-12), confirming C-20 as the methyl carbon attached to the quaternary carbon at C-13. Meanwhile, non-equivalent dimethyl protons at H-18 and H-19 show ${ }^{2} J$ interaction with each other and the quaternary carbon at C-10. Each of the carbinol protons at H-5 and H-8 correlated with the carbonyl group at $\mathrm{C}-3$ and the olefinic methine at $\mathrm{C}-7$ respectively (Figure 3 ).

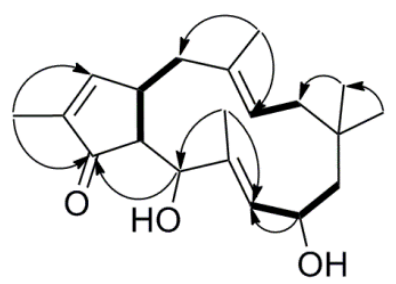

Figure 3. Significant ${ }^{1} \mathrm{H}-{ }^{1} \mathrm{H}$ COSY (-) and $\mathrm{HMBC}(\rightarrow)$ correlations of (-)-5,8-dihydroxyjatrophan-3-one

$(+)-14,16,17$-trihydroxykauran-1-on $(2),[\alpha]_{D}^{25}+30.00\left(c 0.40, \mathrm{CHCl}_{3}\right)$ is a white needle crystal. The IR spectrum showed characteristic absorptions for hydroxyl $\left(3244 \mathrm{~cm}^{-1}\right)$, and carbonyl $\left(1696 \mathrm{~cm}^{-1}\right)$ (Figure 4). 


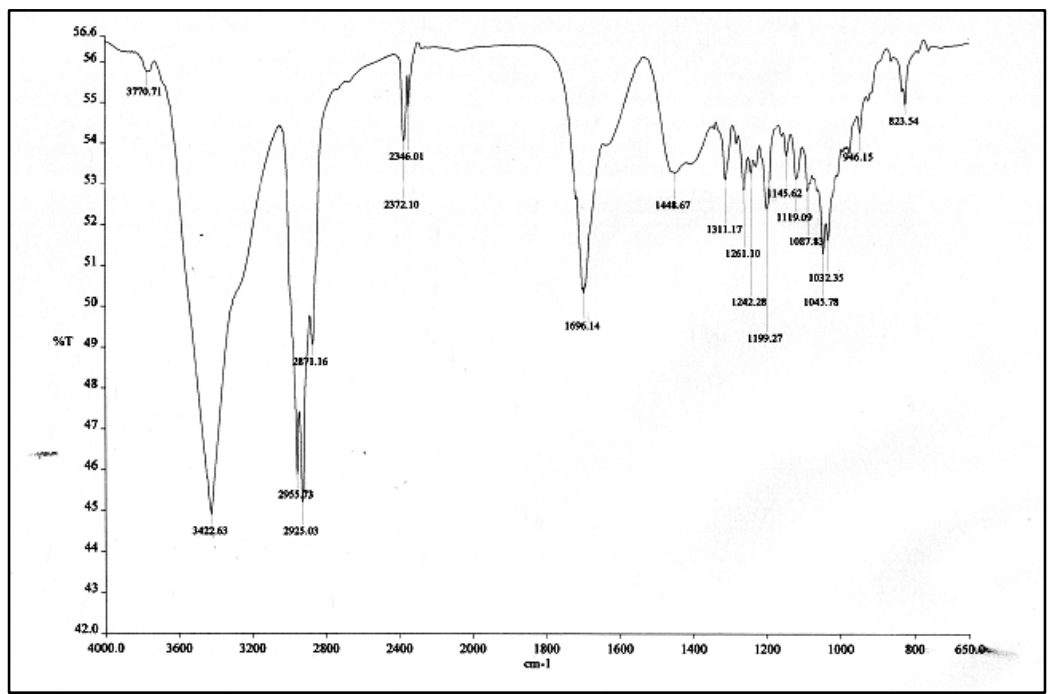

Figure 4. FTIR spectrum of (+)-14,16,17-trihydroxykauran-1-on

This compound contains 20 carbons observed from the ${ }^{13} \mathrm{C}$ NMR spectra, which shows that the compound is made up of three methyls, eight methylenes, four methines and five quaternary carbons (Table 1). The DBE value of five indicates that this compound have four cyclic systems with only one double bond. The highly deshielded carbon at $\delta \mathrm{C} 212.4$ is a carbonyl. Meanwhile, three carbinol carbons appear $\delta_{\mathrm{C}}$ at $76.5(\mathrm{C}-14), 89.5(\mathrm{C}-16)$ and $65.7(\mathrm{C}-17)$. Overlapping carbon signals with a significantly high intensity at $\delta_{\mathrm{C}} 17.5-59.4$ suggest that there is a long chain of cyclic aliphatic carbons. The appearance of a towering signal of protons indicates the presence of a series of long chain methylene groups forming the alkyl of the cyclic aliphatic group along with three hydroxyl groups and three methyls at the terminal of the chain. To determine methylene groups in the alkyl part, mass spectrometer was used. The MS spectral data shows that molecular weight of this compound is $336 \mathrm{~m} / \mathrm{z}\left(\left[\mathrm{M}^{+}+\mathrm{H}-\mathrm{H} 2 \mathrm{O}\right]=319.2259\right)$. Based on the discussion, this compound is identified as (+)-14,16,17-trihydroxykauran-1-on (Figure 5) with molecular formula of $\mathrm{C}_{20} \mathrm{H}_{32} \mathrm{O}_{4}$.

Table 1. ${ }^{1} \mathrm{H}$ and ${ }^{13} \mathrm{C}$ NMR data (500 and $125 \mathrm{MHz}, \mathrm{CDCl}_{3}$ ) for compounds $\mathbf{1}$ and $\mathbf{2}$

\begin{tabular}{lccll}
\hline \multirow{2}{*}{ Position } & \multicolumn{2}{c}{${ }^{13} \mathbf{C}(\mathbf{p p m})$} & \multicolumn{1}{c}{$\mathbf{1}$} & \multicolumn{1}{c}{$\mathbf{H}(\mathbf{\Sigma H}, \mathbf{m u l t} . \mathbf{J} \mathbf{~ i n ~} \mathbf{H z}))$} \\
\cline { 2 - 6 } & $\mathbf{1}$ & $\mathbf{2}$ & \multicolumn{1}{c}{$\mathbf{2}$} \\
\hline 1 & 145.3 & 212.4 & $6.30\left(1 \mathrm{H}, d d, J_{l}=9.5 \mathrm{~Hz}, J_{2}=1.1 \mathrm{~Hz}\right)$ & - \\
2 & 134.6 & 37.8 & - & $2.40(1 \mathrm{H}, s)$ \\
& & & & $2.38(1 \mathrm{H}, d, J=3.5 \mathrm{~Hz})$ \\
3 & 199.7 & 41.4 & - & $1.47(1 \mathrm{H}, m)$ \\
& & & & $1.19(1 \mathrm{H}, d, J=4.0 \mathrm{~Hz})$ \\
4 & 28.1 & 33.2 & $1.53(1 \mathrm{H}, d, J=6.2 \mathrm{~Hz})$ & - \\
5 & 77.4 & 53.2 & $4.13(1 \mathrm{H}, d, J=6.2 \mathrm{~Hz})$ & $1.27\left(1 \mathrm{H}, d d, J_{l}=10.2 \mathrm{~Hz}, J_{2}=\right.$ \\
& & & & $6.9 \mathrm{~Hz})$ \\
6 & 143.7 & 40.2 & - & $1.87(1 \mathrm{H}, m)$ \\
& & & & $1.12\left(1 \mathrm{H}, d d, J_{l}=12.8 \mathrm{~Hz}, J_{2}=3.3\right.$ \\
& & & & $\mathrm{Hz})$ \\
\hline
\end{tabular}


Table 1 (cont'd). ${ }^{1} \mathrm{H}$ and ${ }^{13} \mathrm{C}$ NMR data (500 and $125 \mathrm{MHz}, \mathrm{CDCl}_{3}$ ) for compounds $\mathbf{1}$ and $\mathbf{2}$

\begin{tabular}{|c|c|c|c|c|}
\hline \multirow{2}{*}{ Position } & \multicolumn{2}{|c|}{${ }^{13} \mathrm{C}(\mathrm{ppm})$} & \multicolumn{2}{|c|}{${ }^{1} \mathbf{H}(\Sigma H$, mult., $\mathbf{J}$ in $\left.\mathbf{H z})\right)$} \\
\hline & 1 & 2 & 1 & 2 \\
\hline \multirow[t]{2}{*}{7} & 125.7 & 41.1 & $5.20\left(1 \mathrm{H}, d d, J_{1}=8.0 \mathrm{~Hz}, J_{2}=1.1 \mathrm{~Hz}\right)$ & $\begin{array}{l}2.09\left(1 \mathrm{H}, d d, J_{1}=11.6 \mathrm{~Hz}, J_{2}=\right. \\
3.5 \mathrm{~Hz})\end{array}$ \\
\hline & & & & $1.90(1 \mathrm{H}, m)$ \\
\hline 8 & 67.7 & 56.0 & $5.26\left(1 \mathrm{H}, d d, J_{l}=8.0 \mathrm{~Hz}, J_{2}=6.6 \mathrm{~Hz}\right)$ & - \\
\hline \multirow[t]{2}{*}{9} & 25.5 & 59.4 & $2.09(1 \mathrm{H}, m)$ & $1.86(1 \mathrm{H}, m)$ \\
\hline & & & $0.78(1 \mathrm{H}, m)$ & \\
\hline 10 & 29.8 & 36.9 & - & - \\
\hline \multirow[t]{3}{*}{11} & 31.6 & 18.2 & $2.31(1 \mathrm{H}, m)$ & $1.66\left(1 \mathrm{H}, d d, J_{1}=11.6 \mathrm{~Hz}, J_{2}=\right.$ \\
\hline & & & $2.25(1 \mathrm{H}, m)$ & $3.5 \mathrm{~Hz})$ \\
\hline & & & & $1.50(1 \mathrm{H}, m)$ \\
\hline \multirow[t]{2}{*}{12} & 119.4 & 43.4 & $4.70\left(1 \mathrm{H}, d d d, J_{1}=9.5 \mathrm{~Hz}, J_{2}=4.0 \mathrm{~Hz}\right.$ & $2.14(1 \mathrm{H}, d, J=11.6 \mathrm{~Hz})$ \\
\hline & & & $\left.J_{3}=1.1 \mathrm{~Hz}\right)$ & $1.57(1 \mathrm{H}, m)$ \\
\hline 13 & 137.7 & 41.5 & - & $2.61(1 \mathrm{H}, t, J=6.5 \mathrm{~Hz})$ \\
\hline \multirow[t]{2}{*}{14} & 39.9 & 76.5 & $2.23(1 \mathrm{H}, m)$ & $4.48(1 \mathrm{H}, s)$ \\
\hline & & & $1.70(1 \mathrm{H}, m)$ & \\
\hline \multirow[t]{2}{*}{15} & 35.8 & 46.4 & $1.19(1 \mathrm{H}, d, J=9.5 \mathrm{~Hz})$ & $2.04(1 \mathrm{H}, d, J=12.0 \mathrm{~Hz})$ \\
\hline & & & & $1.69(1 \mathrm{H}, m)$ \\
\hline 16 & 12.1 & 89.5 & $1.95(3 \mathrm{H}, d, J=1.1 \mathrm{~Hz})$ & - \\
\hline \multirow[t]{2}{*}{17} & 10.3 & 65.7 & $1.72(3 \mathrm{H}, d, J=1.5 \mathrm{H})$ & $3.83(1 \mathrm{H}, d, J=12.0 \mathrm{~Hz})$ \\
\hline & & & & $3.64(1 \mathrm{H}, d, J=12.0 \mathrm{~Hz})$ \\
\hline 18 & 16.1 & 21.3 & $1.03(3 \mathrm{H}, s)$ & $0.85(3 \mathrm{H}, s)$ \\
\hline 19 & 29.3 & 33.3 & $1.17(3 \mathrm{H}, s)$ & $0.87(3 \mathrm{H}, s)$ \\
\hline 20 & 15.4 & 17.5 & $1.61(3 \mathrm{H}, d, J=1.1 \mathrm{~Hz})$ & $1.25(3 \mathrm{H}, s)$ \\
\hline
\end{tabular}

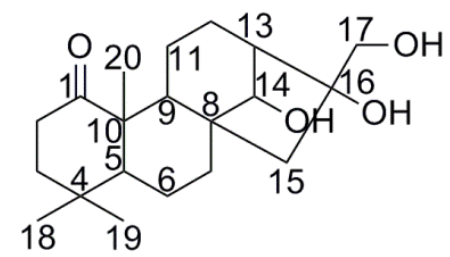

Figure 5. Chemical structure of (+)-14,16,17-trihydroxykauran-1-on

The structure of the compound was further confirmed using 2D NMR experiments including HMBC and COSY. From the HMBC experiments, the position of carbonyl carbon (C-1) was proven by correlations of C-2, C-5 and C20 toward C-1. The proton H-14 in correlation with C-9 confirmed the position of this carbinol group bonded to C-8 and $\mathrm{C}-13$ as branches to the other two carbinol groups at $\mathrm{C}-16$ and $\mathrm{C}-17$. COSY spectrum shows correlations between four proton methylene $(\mathrm{H}-2, \mathrm{H}-3, \mathrm{H}-6, \mathrm{H}-7, \mathrm{H}-11$ and $\mathrm{H}-12)$ that forms the unsubstituted aliphatic component of the main ring skeleton in the molecule (Figure 6). 


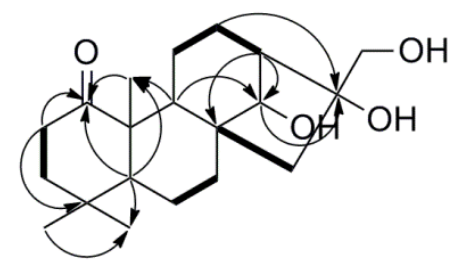

Figure 6. Significant ${ }^{1} \mathrm{H}-{ }^{1} \mathrm{H}$ COSY (-) and $\operatorname{HMBC}(\rightarrow)$ correlations of (+)-14,16,17-trihydroxykauran-1-on

\section{Chemotaxonomic significance}

The genus Croton is the second largest genus of Euphorbiaceae with over 1300 species, and over 100 species from this genus have been studied phytochemically, resulting in the isolation and identification of more than 200 various types of diterpenoids) [21,22] comprising of different skeleton types such as clerodane (most common), kaurane, cembranoid, halimane, isopimarane, labdane, phorbol and trachylobane [23].

In this study, a new jatrophane and kaurane-type diterpenoid, (-)-5,8-dihydroxyjatrophan-3-one (1) and (+)14,16,17-trihydroxykauran-1-on (2) respectively, was obtained from the roots of $C$. hirtus. The occurrence of diterpenoids in Euphorbiaceae is not unusual. Compounds with jatrophane-type skeleton was isolated from the genus Jatropha for the first time, and widely identified in the other genera (Euphorbiaceae) as well. The roots and rhizomes of several Jatropha species was reported to contain jatrophone, hydroxyjatrophone A-C, 9ק-

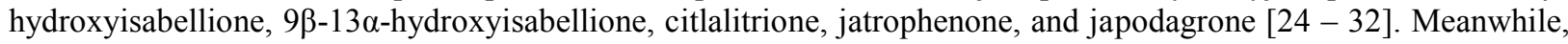
four jatrophane polyesters were isolated from the aerial parts of the East Asian weed Euphorbia mongolica Prokh [33].

In 2010, Hegazy et al. [34] identified the new guyonianin E and $\mathrm{F}$ from the aerial parts of Euphorbia guyoniana. Meanwhile, euphodendrophane A (Euph A) and euphodendrophane B (Euph B) were isolated from the jatrophane fraction of Euphorbia dendroidesn L. [35]. Since only these two genera were reported to biologically synthesize diterpenoid, thus chemotaxonomically, it can be assumed that the genus Croton is related to genera Jatropha and Euphorbia. Despite the large number of kaurane-type diterpenoids isolated from this genus, some species from other families also show the presence of this diterpenoid subclass. Four ent-kaurane diterpenoid glycosides, cussovantosides A-D were isolated with other known compounds from the dried leaves of Cussonia vantsilana Baker (Araliaceae) [36]. Other ent-kaurane derivatives such as ent-16- kauren-19-oic acid (kaurenoic acid) methyl ester, grandiflorenic acid methyl ester, ent-16-kauren-19-al, 16 $\alpha$,17- epoxy-15 $\alpha$-angeloyloxykauran-19-oic acid methyl. Grandiflorenic acid and 15- $\alpha$-angeloyloxy-16,17- $\alpha$-epoxy- ent-16-kauren-19-oic acid were present only in the Asteraceae plant Smallanthus sonchifolius and Smallanthus siegesbeckius [37].

\section{Conclusion}

Two diterpenoids; (-)-5,8-dihydroxyjatrophan-3-one (1) and (+)-14,16,17-trihydroxykauran-1-on (2) were successfully isolated from the methanolic extract of Croton hirtus. To the best of our knowledge, this is the first report for both compounds from this species. Both of compounds can be used to carry out biological activities because this species was known as many useful in traditional medicine.

\section{Acknowledgement}

We would like to thank the School of Chemical Sciences and Food Technology, Faculty of Science and Technology, Universiti Kebangsaan Malaysia (UKM) and Malaysia Genome Institute for providing research facilities. Authors also would like to express our gratitude to the LPDP (Indonesia Endowment Fund for Education), DIKTI and the Ministry of Science and Technology and Universiti Kebangsaan Malaysia for financial support through research grant of IRPA 09-02-02-0086-EA227, GGPM-2013-076 and FRGS-1-2014-SG01-UKM-02-5, respectively.

\section{References}

1. Soernaji, M., Kostermans, A. J. G. H. and Tjittrosoepomo, G. (1976). Weed of rice in Indonesia. Balai Pustaka. Jakarta. 
2. Boonyarathanakornkit, L., Che, C., Fong, H. H. S. and Farnsworth, N. R. (1987). Constituents of Croton crassifolius roots. Planta Medica, 54: 61-62.

3. Siems, K., Dominguez, X. A. and Jakupovic, J. (1992). Diterpenes and other constituents from Croton cortesianus. Phytochemistry, 40: 4363-4365.

4. Ngadui, B. T., Abegaz, B. M., Keumedjio, F., Folefoc, G. N. and Kapche, G. W. F. (2002). Diterpenoids from the stem bark of Croton zambesicus. Phytochemistry, 60: 345-349.

5. Aguilar-Guadarrama, A. B. and Rios, M. Y. (2004). Three new sesquiterpenes from Croton arboreous. Journal of Natural Products, 67: 914-917.

6. Chatterjee, A., Banerjee, A. and Bohlman, F. (1977). Crotocaudin: A rearranged labdane type nor-diterpene from Croton caudatus Geisel. Tetrahedron, 33: 2407-2414.

7. Craveiro, A. and Silveira, E. R. (1982). Two cleistanthane type diterpenes from Croton sonderianus. Phytochemistry, 21: 2571-2574.

8. Monte, F. J. R., Dante, E. M. G. and Braz, R. (1988). New diterpenoids from Croton argyarophylloides. Phytochemistry, 27: 3209-3212.

9. Ichihara, Y., Takeya, K., Hitotsuyanagi, Y., Morita, H. and Itokawa, H. (1992). Cajucarinolide and isocajucarinolide: Anti-inflammatory diterpenes from Croton cajucara. Planta Medica, 58: 549-551.

10. Babili, F. E., Moulis, C., Bon, M., Respaud, M. J. and Fouraste, I. (1998). Three furano-diterpenes from the bark of Croton campestris. Phytochemistry, 48: 165-169.

11. Farias, A. C. G., Melo, P. S., Aoyama, H., Haun, M., Duran, N. and Ferreira, C. V. (2002). Cytotoxic effect of the diterpene lactone dehydrocrotonin from Croton cajucara on human promyelocytic leukemia cells. Planta Medica, 69: 67-69.

12. Puebla, P., Correa, S. X., Guerrero, M., Carron, R. and San Feliciano, A. (2005). New cis-clerodane diterpenoids from Croton schiedeanus. Chemical Pharma Bulletin (Tokyo), 53: 328-329.

13. Norizan Ahmat, A. H., Ikram M. S., Jalifah Latip, Laily B. D., Syah Y. M. and Euis H. H. (2007). Styryldehydropyrone and clerodane-type diterpene from Croton argyratus. Malaysian Journal of Analytical Sciences, 11(1): 189-192.

14. Maciel, M. A. (2000). Ethnopharmacology, phytochemistry and pharmacology a successful combination in the study of Croton cajucara. Journal of Ethnnopharmacology, 70: 41-45.

15. Barbosa, P. R., Fascio, M., Martins, D., Maria, L., Guedes, S. and Roque, N. F. (2003). Triterpenes of Croton betulaster (Euphorbiaceae). Biochemical Systematics and Ecology, 31: 307-308.

16. Mulholland, D. A., Langat, M. K., Crouch, N. R., Coley, H. M., Mutambi, E. M. and Nuzillard, J. (2010). Cembranolides from the stem bark of the southern African medicinal plant, Croton gratissimus (Euphorbiaceae). Phytochemistry, 71: 1381-1386.

17. Gelaw, H., Adane, L., Tariku, Y. and Hailu, A. (2012). Isolation of Crotepoxide From Berries of Croton macrostachyus and Evaluation of Its Anti-Leishmanial Activity. Journal of Pharmacognosy and Phytochemistry, 1(4):15-24.

18. Kawakami, S., Matsunami, K., Otsuka, H., Shinzato, T. and Takeda, H. (2011). Crotonionosides A-G: Megastigmane glycosides from leaves of Croton cascarilloides Räuschel. Phytochemistry, 72: 147-153.

19. Fuentes, J. C., Castro, V., Jakupovic, J. and Murillo, R. (2004). Diterpenos y otros constituyentes de Croton hirtus (Euphorbiaceae). Revista de Biología Tropical, 52(1): 269-285.

20. de Lima, S. G., Medeiros, L. B. P., Cunha, C. N. L. C., da Silva, D., de Andrade, N. C., Moita Neto, J. M., Lopes, J. A.D., Steffen, R. A., Araújo, B. Q. and Reis, F. de A. M. (2012). Chemical composition of essential oils of Croton hirtusL'Her from Piauí (Brazil). Journal of Essential oil Research, 24(4): 371-376.

21. Puebla, P., Lopez, J. L., Guerrero, M., Carron, R., Martin, M. L., Roman, L. S. and Feliciano, A. S. (2003). Neo-Clerodane diterpenoids from Croton Schiedeanus. Phytochemistry, 62: 551-555.

22. Barbosa, P. S., Abreu, A. S., Batista, E. F., Guilhon, G. M. S. P., Müller, A. H., Arruda, M. S. P., Santos, L. S., Arruda, A. C. and Secco, R. S. (2007). Glutarimide alkaloids and terpenoids from Croton pullei var. glabrior Lanj. Biochemical Systematics and Ecology, 35: 887-890.

23. Yang, X. D., Chen, W., Zhao, J. F., Yang, L. J., Zhang, H. B., Li, L. (2009). Ent-kaurane diterpenes and phenolic compounds from Croton kongensis (Euphorbiaceae). Biochemical Systematics and Ecology, 37: $237-$ 240. 
24. Kupchan, S. M., Sigel, C. W., Matz, M. J., Saenz Renauld, J. A., Haltiwanger, R. C. and Bryan, R.F. (1970). Jatrophone, a novel macrocyclic diterpenoid tumor inhibitor from Jatropha gossypiifolia. Journal of American Chemical Society, 92(14:, 4476-4477.

25. Kupchan, S. M., Sigel, C. W., Matz, M. J., Gilmore, C. J. and Bryan, R. F. (1976). Structure and stereochemistry of jatrophone, a novel macrocyclic diterpenoid tumor inhibitor. Journal of American Chemical Society, 98(8): 2295-2300.

26. Taylor, M. D., Smith, A. B., Furst, G. T., Gunasekara, S. P., Bevelle, C. A., Cordell, G. A., Farnsworth, N. R., Kupchan, S. M., Uchida, H., Branfman, A. R., Daily, R. G. and Sneden, A. T. (1983). Plant anticancer agents. 28. New antileukemic jatrophone derivatives from Jatropha gossypiifolia: structural and stereochemical assignment through nuclear magnetic resonance spectroscopy. Journal of American Chemical Society, 105: 3177-3183.

27. Goulart Marilla, O. F., Sant'Ana, Antonio Euzebio G., De Lima, Roberto A., Cavalcante Sergio, H., De Carvalho, Mario G., Braz Filho and Raimundo .(1993). Fitoconstituintes Químicos Isolados de Jatropha elliptica. Atribuição dos Deslocamentos Químicos dos Átomos de Carbono e Hidrogênio dos Diterpenos Jatrofolonas A e B. Química Nova, 16(2): 95-100.

28. Das, B. and Venkataiah, B. (1999). A rare diterpene from Jatropha gossypiifolia. Biochemical Systematics and Ecology, 27: 759-760.

29. Ravindranath, N., Venkataiah, B., Ramesh, C., Jayaprakash, P. and Das, B. (2003). Jatrophenone, a Novel Macrocyclic Bioactive Diterpene from Jatropha gossypifolia. Chemical and Pharmaceutical Bulletin, 51(7): 870-971.

30. Aiyelaagbe, O. O., Adesogan, E. K., Ekundayo, O. and Gloer, J. B. (2007). Antibacterial diterpenoids from Jatropha podagrica Hook. Phytochemistry, 68: 2420-2425.

31. Pertino, M., Schmeda-Hirschmann, G., Rodríguez, J. A. and Theoduloz, C. (2007). Gastroprotective effect and cytotoxicity of terpenes from the Paraguayan crude drug "yagua rova" (Jatropha isabelli). Journal of Ethnopharmacology, 111: 553-559.

32. Das, B., Laxminarayana, K., Krishnaiah, M., Srinivas, Y. and Raju, T. V. (2009). Multidione, a novel diterpenoid from Jatropha multifida. Tetrahedron Letters, 50: 4885-4887

33. Rédei, D., Forgo, P., Molnár, J., Szabó, P., Zorig, T. and Hohmann, J. (2012). Jatrophane diterpenoids with multidrug resistance-modulating activity from Euphorbia mongolica Prokh. Tetrahedron, 68: 8403-8407.

34. Hegazy, M. E. F., Mohamed, A. E. H., Aoki, N., Ikeuchi, Ohta, E. and Ohta, S. (2010). Bioactive jatrophane diterpenes from Euphorbia guyoniana. Phytochemistry, 71: 249-253.

35. Pešić, M., Banković, J., Aljančić, I. S., Todorović, N. M., Jadranin, M., Vajs, V. E., Tešević, V. V., Vučković, I., Momčilović, M., Marković, I. D., Tanić, N. and Ruždijić, S. (2011). New anti-cancer characteristics of jatrophane diterpenes from Euphorbia dendroides. Food and Chemical Toxicology, 49: 3165-3173.

36. Harinantenaina, L., Kasai, R. and Yamasaki, K. (2002). Ent-kaurane diterpenoid glycosides from a Malagasy endemic plant, Cussonia vantsilana. Phytochemistry, 61: 367-372.

37. Aráoz, M. V. C., Mercado, M. I., Grau, A. and Catalán, C. A. N. (2010). Ent-kaurane derivatives from the root cortex of yacon and other three Smallanthus species (Heliantheae, Asteraceae). Biochemical Systematics and Ecology, 38: 1042-1048. 